\title{
HUMAN RESOURCE MANAGEMENT: Disparity in Labor Productivity against Contributions between the Development Sector in Bengkulu Province
}

\author{
Ahmad H Sutawijaya, Badawi Saluy, Masyhudzulhak \\ Pascasarjana, Universitas Mercu Buana
}

\begin{abstract}
The purpose of this study to analyze Disparities in labor productivity of the contribution sector to the Gross Regional Product Domestic Bengkulu province. For this writing obtained data from the research literature and Agencies Bengkulu Province Department of Labor and Statistics Indonesia Bengkulu Province. Labor problems in Bengkulu province at present the disparity in labor productivity among the nine regional development sector. The agricultural sector is the most labor-intensive and provides the largest contribution to the Gross Regional Demostik Product (GDP). However, labor productivity of small amount of the contribution the agricultural sector is not adding value to agricultural laborers. The conclusion in this paper; (I) the disparity between the productivity of labor in the construction sector (ii) institutional working workforce has not run optimally (ii) workforce management strategies must work to strengthen good governance and work integrated workforce planning (iii) strengthening social capital.
\end{abstract}

Keyword: Productivity, Employee, Disparity

\section{INTRODUCTION}

Labor productivity is the ability of human resources, in implementing the work plan and get the plan in accordance with the set. Labor productivity is the ratio of output (results) with the input (feedback). Important factors in productivity in the form of a positive working attitude and competence that is reflected from the education and training of individual labor and minimum physical needs of a person's labor. The low level of education or the inability of the charge of skill and a skill greatly affect productivity. Productivity according Tjutju Yuniarsih and Suwatno (2008) productivity as the value of output in the interaction and unity interealsinya with input values.

ILO (International Labour Organization) in Sumarsono (2003) stated productivity is the ratio between the elements of production with which it produces a measure of productivity. Encyclopedia of Professional Management in BITTEL, RL. and Rampsey.J.E (1985) stated that productivity is a measure of the extent to which those resources are combined and utilized properly can realize certain results desired.Productivity of the quality of human resources, development of human resources by Ginting (2006) was highly correlated with changes Knowledge, Skill, and Attitude. Sumitro (1994) states that education is a prerequisite for improving human dignity. Through education, citizens have the opportunity to develop his ability and set a reasonable life.

Strategic productivity outlined above illustrates the importance of the role of a local workforce for productivity greatly affect the rate of production area. Furthermore, the productivity of human resources a success indicator of the area and more importantly labor productivity reflects whether the equitable distribution of local production have been achieved. If an area tingak low labor productivity is not yet even describe the skill and educational levels of workers. The impact of the low productivity of labor productivity disparities that have occurred in the development sectors.

In general, labor productivity Indonesia is still unable to compete with a workforce of neighboring countries (ASEAN) on the report of the Institute for Management Development (2009) states that the productivity of labor tenga Indonesia is still low with Malaysia and Tahiland. Complete display and table 1 below: 
Ahmad H Sutawijaya et al.

Table1. Productivity Study Results to Asian Countries

\begin{tabular}{|c|c|c|c|c|c|c|c|c|c|}
\hline \multirow{2}{*}{$\begin{array}{l}\text { Country } \\
\text { Name }\end{array}$} & \multicolumn{9}{|l|}{ Year } \\
\hline & 1999 & 2000 & 2001 & 2002 & 2003 & 2004 & 2005 & 2006 & 2007 \\
\hline Singapura & 2 & 2 & 2 & 5 & 2 & 2 & 2 & 2 & 2 \\
\hline Malayasia & 9 & 9 & 10 & 6 & 4 & 16 & 28 & 23 & 23 \\
\hline China & 11 & 11 & 12 & 12 & 12 & 24 & 31 & 19 & 15 \\
\hline Tahiland & 16 & 13 & 14 & 13 & 12 & 29 & 27 & 32 & 33 \\
\hline Filpina & 31 & 37 & 40 & 40 & 22 & 52 & 49 & 49 & 45 \\
\hline Indonesia & 47 & 44 & 49 & 47 & 28 & 58 & 59 & 60 & 54 \\
\hline
\end{tabular}

Source. Aroef and Jamal Year 2009

Views of table 1 above a fact that is very hard to accept the results of the survey, but this fact needs to be addressed as future challenges in human resource development. The study Institute for Management Devlopment (IMD) and the results of a study World Economic Forum (WEF) beginning in 1999-2007 released the results of a survey of productivity for Asian countries this report shows the productivity of human resources in Indonesia there is progress but remained as the country lags behind with other Asian countries (see Table 2). According data from the Institute for Management Devlopment (IMD) that reflect the level of productivity we are far behind the other nations. The results of these data need to re-arranger of human resource management in Indonesia, due to the development of human resources is very important. Data that support from the Institute for Management Devlopment linkages also with Human Deplovmen Index (HDI). HDI level of Indonesia and other countries to rank 110 this is still far compared to singapore and malaysia. More are presented in Table 2 below.

Table2. Results Study HDI rating of ASEAN Countries

\begin{tabular}{|c|c|c|c|c|c|c|}
\hline \multirow{3}{*}{ Country Name } & \multicolumn{3}{|c|}{ Year 1995} & \multicolumn{3}{|c|}{ Year 2005} \\
\hline & \multirow[t]{2}{*}{ HDI } & \multicolumn{2}{|c|}{ Ranking } & \multirow[t]{2}{*}{ HDI } & \multicolumn{2}{|c|}{ Ranking } \\
\hline & & World & Asean & & World & Asean \\
\hline Singapura & 0,865 & 34 & 1 & 0,922 & 25 & 1 \\
\hline Malaysia & 0,763 & 52 & 3 & 0,811 & 73 & 4 \\
\hline Tahiland & 0,745 & 53 & 4 & 0,781 & 61 & 3 \\
\hline Filpina & 0,739 & 95 & 5 & 0,771 & 84 & 5 \\
\hline Vietnam & 0,672 & 102 & 6 & 0,733 & 110 & 7 \\
\hline Indonesia & 0,670 & 121 & 7 & 0,728 & 108 & 6 \\
\hline
\end{tabular}

Source. UNDP in basri Year 2009

The survey results show the 1995 and 2005 UNDP HDI levels Indonesia rate of development is no increase in labor productivity but Indonesia is still lagging behind with ASEAN countries. This indicates the ability and level of education of Indonesian workers on average still low in comparison with the ASEAN countries, low levels of education lead to lower worker productivity. The above figures are real human resource development is not at the level that both the rate of development even decreased when compared to Asean countries. If seen from the development pace of the Indonesian Human Devlopment Index of nominal growth figures increased from 0.670 into 0.728 . But still tertingalnya Indonesia to neighboring countries it is possible that there is a tendency that the state of Singapore and Malaysia continue to enhance the development of Human Resources.

From the above problems occurring is inseparable from the human resources management system which has been centralized without regard to the potential and carrying capacity and existing capacity. Management has focused physical development and less attention to the things that are the competence and character of the human capital base as human resources that includes psychology, and social culture. So do not give space to support the growth of human resources to improve the quality excellent and competitive. According to table 2, it can be seen that the problems emerging issues in human resource development; First, the low quality of human resources is reflected in the level of human resources workforce. Both development human resources not be a driving force of regional development.

\section{Review of MANagement Human ReSOURCES IN THE Region}

Bengkulu Province is a newly developed area with limited natural resources should anticipate an early stage of development and globalization at this time. Readiness to anticipate this change must begin a conceptual and contextual in the development of human resources. 
Problems that arise in the management of human resources yatiu; (I) the weak infrastructure of human resource development, (ii) lack of institutional coherence in all lines of a government organization, (iii) in addition to the direction and goals are not clearly mengkaitan the focus of local economic and local wisdom Bengkulu Province. As a consideration the human development index in general still are not too high but not too low which is reflected in the human development index.

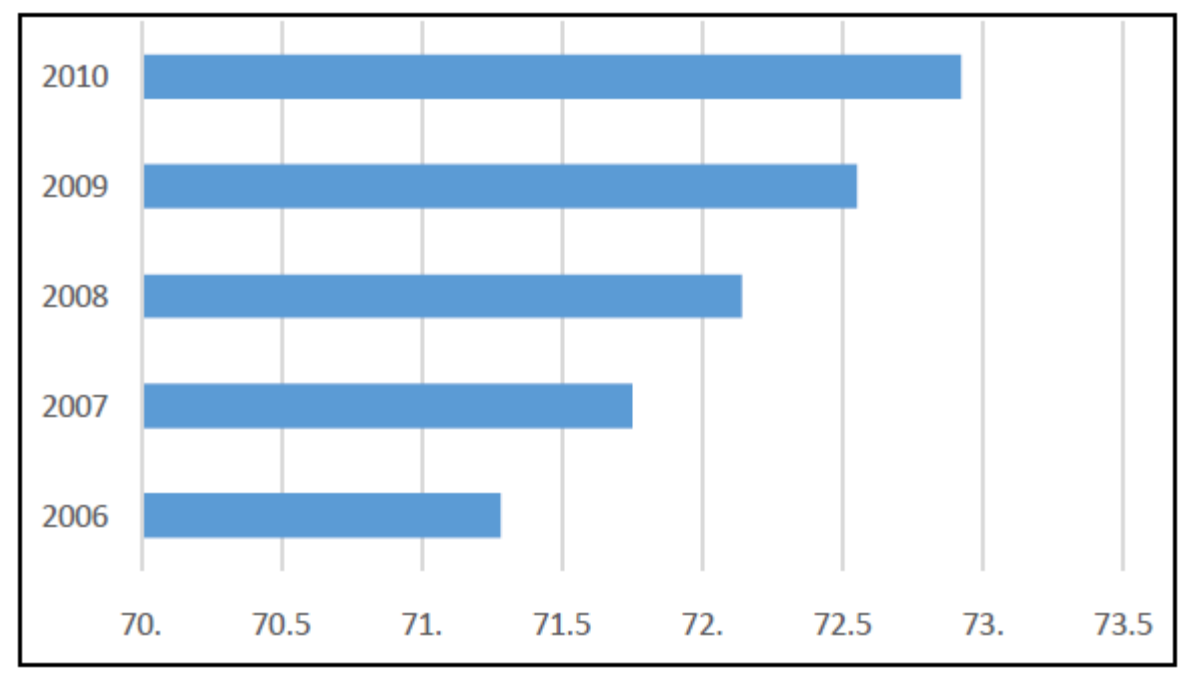

Source. Elfendri and Fitri Rasmita, 2006

Figure1. HDI Index Bengkulu Province

For labor above elementary school (SD) or high school (High School (SMU)) and D1 - D3 so on, graduate college is not all the labor force is absorbed by the formal sector. Data from the Department of manpower and transmigration for 2007 educated level job seekers high school up to college search registered recorded more or less of the total labor force 7.31 of Bengkulu province. Prominently displayed in table 3. From figure (graphic) 3 the index of human resource management in Bengkulu province is closely linked to the level of labor productivity in the provinces of Bengkulu, in general workforce in Bengkulu province in the low category. The precentage of total employment in the province of Bengkulu $61 \%$ level of workforce education is not complete primary school and completed primary education (CBS, 2004) and in general the labor force in the agricultural sector absorbed the informal nature. Data from the Department of Manpower and Transmigration to 2007 job seekers educated secondary school level up to the College of registered as a job seaker recorded approximately $7.31 \%$ of the total labor force of Bengkulu province.

Table3. Number of Labor Education Year 2006

\begin{tabular}{|l|l|c|}
\hline No & Graduates & Amount \\
\hline 1. & SLTA (SMU) & 37.830 \\
\hline 2. & Diploma I \& II & 1.938 \\
\hline 3. & Diploma III & 5.809 \\
\hline 4. & Sarjana & 12.350 \\
\hline 5. & Jumlah & 57.927 \\
\hline
\end{tabular}

Source. Department of Labor and Trans, 2006

Table 3 above shows high enough educated job seekers showed formal employment opportunities have not been able to absorb the labor force this is due to the limited formal labor market. From the table above, most job seekers who are high school graduates and S1 (undergraduate) this case illustrates the number of job seekers with higher education levels showed considerable imbalance of supply and labor market demand. Impact unbalance mechanism labor market, educated labor becomes unemployment labor into the informal sector that does not comply with the educational level of human resources.

\section{IMBALANCE LABOR STRUCTURAL}

Employment in the province of Bengkulu in general is a graduate of SMP / MTsN and SMA / SMK MTs Aaliah and SMK clearly as the following. 


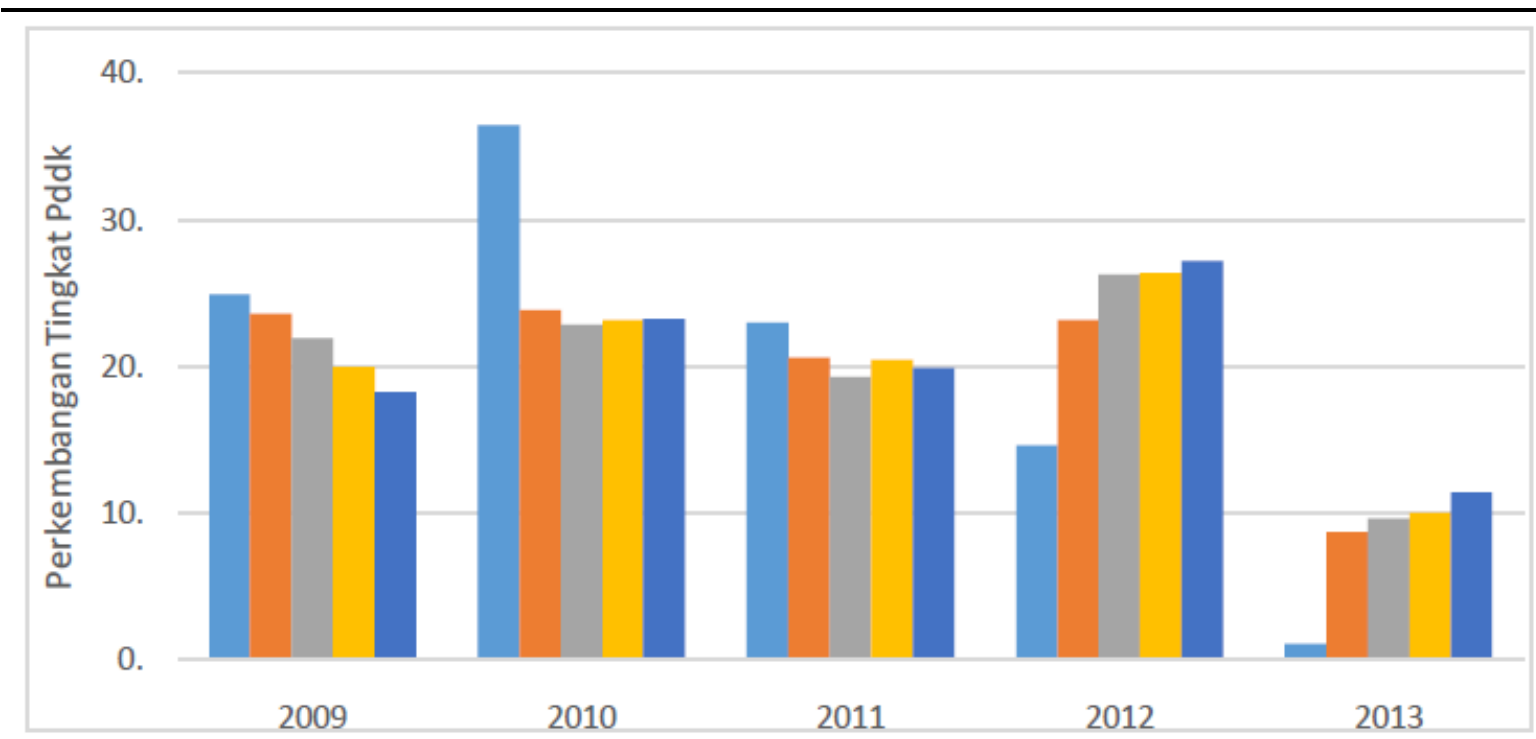

Figure2. Level of Education Workers of the Province of Bengkulu

Table 2 above graph illustrates the level of education that is dominant in fulfilling the labor market absorption is not completed primary school, complete primary school, graduated SMP / MTs and SMA / MA / SMK.

Furthermore workforce gaps in the province of Bengkulu in employment for workers in the Bengkulu Province not completed elementary school, elementary school graduation, junior high school in general entering the non-formal employment, especially in agriculture and the informal sector (see table 4)

Table4. Percentage of Population Aged 15 Years To Top Work according to the Employment Year 2008 - 2013

\begin{tabular}{|l|l|l|l|}
\hline \multirow{2}{*}{ Field Work } & \multicolumn{3}{c|}{ Year } \\
\cline { 2 - 4 } & 2008 & 2010 & 2013 \\
\hline Agriculture & 65,29 & 58,16 & 52,16 \\
\hline Mining & 1,06 & 1,08 & 1,19 \\
\hline Industry & 2,66 & 2,52 & 3,08 \\
\hline Electricity/Water & 0,09 & 0,15 & 0,17 \\
\hline Construction & 4,48 & 4,34 & 4,63 \\
\hline Trading & 12,52 & 15,45 & 17,20 \\
\hline Transport and Communication & 3,62 & 3,01 & 2,62 \\
\hline Bank/Others Finance Institution & 0,31 & 0,86 & 2,06 \\
\hline Service/Other sector & 10,16 & 14,53 & 16,89 \\
\hline
\end{tabular}

Sumber. BPS Provinsi Begkulu

Table 4 above shows the population aged over 15 working according to employment data in the Bengkulu Province from 2008 s / d 2013 absorption greatest employment to absorb labor; (I) agriculture, (ii) trade, (iii) services and other sectors. The agricultural sector is the most laborintensive high absorption of the agricultural labor force in the province of Bengkulu directly or indirectly, this sector also affects labor productivity area. Other impacts the amount of labor in the agricultural sector has attracted a highly educated work force so that the occurrence of low employe (tenga work which is not in accordance with the level of education) enter the labor market. This is because the size of the labor force that has not been absorbed by the labor market is the appropriate level of education.

The entry of educated labor force in the informal sector is a "bad thing" because in general the informal sector has a relatively low level of productivity, it is not comparable to the costs incurred in the study. So that this sector can improve productivity needs to do a better arrangement and structured, so that it becomes productive sectors and efficient in the management of human resources. The amount of absorption of labor force in the agricultural sector is a challenge for policy makers in this area in determining the human resource development policy that is made of human resources who are trained and have the skills to improve the productivity of the formal and informal sectors in order to become better. 
HUMAN RESOURCE MANAGEMENT: Disparity in Labor Productivity against Contributions between the Development Sector in Bengkulu Province

\section{Overview of Labor Productivity and Production Disparities Labor}

The influence of labor productivity to economic development is described in two things: the macro effect of the contribution of labor productivity to the GDP (Gross Demostik product of a region), drawn from table 7. The most sector was contributed for the development in Bengkulu province are agriculture, but if measured by labor productivity agricultural work productivity levels are very low. The low productivity of this sector due influenced by internal and external factors. Internal factors still low skill and labor skills. External factors have not awakening the integration of stakeholders (government, business and society). The contribution of agriculture sector to the regional economy at the macro contributes nearly $50 \%$ of demostik gross regional product (GDP) but the average labor productivity of farmers is very small when compared to the banking sector it is inversely proportional.

In general, agricultural laborers require less labor skill and ability levels are high, do the analysis obtained from the agricultural sector productivity growth compared with other production sectors in the area displayed in Table 5. The amount of labor absorbed in the agricultural sector affects productivity, the agricultural sector contributed the largest contribution to the production area from 2000-2004 at demostik gross regional product (GDP).

Table5. Analysis of the Labor and Delivery Sector Contributions Disparities Regional Development

\begin{tabular}{|c|c|c|c|c|c|c|c|c|c|}
\hline \multirow[b]{4}{*}{ Job Demand } & \multicolumn{9}{|c|}{ Years } \\
\hline & \multicolumn{3}{|c|}{2008} & \multicolumn{3}{|c|}{2010} & \multicolumn{3}{|c|}{2013} \\
\hline & \multicolumn{3}{|c|}{$\%$} & \multicolumn{3}{|c|}{$\%$} & \multicolumn{3}{|c|}{$\%$} \\
\hline & TK & Kont & Prod & TK & Kont & Prod & TK & Kont & Prod \\
\hline Agriculture & 65,29 & 40,66 & 0,62 & 58,16 & 40,23 & 0,69 & 52,16 & 38,97 & 0,74 \\
\hline Mining & 1,06 & 3,35 & 3.16 & 1,08 & 4,15 & 3,8 & 1,19 & 3,88 & 3.2 \\
\hline Industry & 2,66 & 4,31 & 1,66 & 2,52 & 4,21 & 1,67 & 3,08 & 4,49 & 1,45 \\
\hline Electricity/Water & 0,09 & 0,46 & 5.11 & 0,15 & 0,53 & 3.5 & 0,17 & 0,53 & 3.11 \\
\hline Construction & 4,48 & 3,22 & 0,718 & 4,34 & 3,11 & 0,70 & 4,63 & 3,80 & 0,82 \\
\hline Trading & 12,52 & 19,77 & 1,57 & 15,45 & 19,87 & 1,28 & 17,20 & 8,04 & 0,46 \\
\hline $\begin{array}{l}\text { Transport and } \\
\text { Communication }\end{array}$ & 3,62 & 8,46 & 2,33 & 3,01 & 8,43 & 2,8 & 2,62 & 8,07 & 3,08 \\
\hline $\begin{array}{l}\text { Bank/Other Banking } \\
\text { Institution }\end{array}$ & 0,31 & 4,41 & 14.22 & 0,86 & 4,98 & 5,7 & 2,06 & 4,98 & 2,40 \\
\hline Service/Others sector & 10,16 & 1938 & 1,90 & 14,53 & 17,31 & 1.19 & 16,89 & 16,54 & 0,9 \\
\hline
\end{tabular}

Sumber. diolah dari BPS Provinsi Bengkulu 2008, 2010, 2013.

\section{$T k=$ Tenaga Kerja, Kont $=$ Kontribusi, Prod $=$ Produktivitas.}

Table high contribution of the agricultural sector GDP is not a linear effect on the rate of labor productivity in the agricultural sector in table 5 the average level of labor productivity in this sector from 2000-2004 was 0.58. Low labor productivity agricultural sector due to the sector in general still is informal with still traditional processing. Sectors that average labor productivity levels higher than in 2000-2004, among others, institutional banking and finance sector was 12.7 and the mining sector amounted to 7.02 .

Other sectors whose productivity is high, such as transportation, communications, an average of 3.46. The high productivity of sectors because these sectors of production using high technology and capital-intensive enough and the employment needs an educated work force. Exposure to the above results (Table 5) show that the factor of human resources in the development of the region play an important role, in addition, other factors also had a big hand is the capital and technological factors. Therefore it can be concluded that there is a close relationship between level of education and skill affect the productivity and labor life.

\section{Human Resources Management Strategy}

Human resource management can be achieved, namely the establishment of good governance that give it a role in the management of human resources, namely (i) government, (ii) business, (iii) community. The integration of three pillars can be achieved human resource management of high productivity and competitiveness ber.

Local governments and legislators as policy makers and development management must be able to be with other stakeholders respond to the challenges and opportunities in realizing the enhancement of 
the whole development in accordance with the carrying capacity and carrying capacity of the area. By making the Long Term Development Plan (RPJP) and the Vision and Mission Regional Head as outlined in the medium-term development plan (Plan). In the execution should enable the institution related directly involved, especially the relevant agencies and NGO communities.

For the models offered in reducing disparities in labor productivity in the provinces of Bengkulu form Framework in Table 6.

Table6. Framework Strategy to Improve Human Resources

\begin{tabular}{|c|c|c|c|}
\hline \multicolumn{4}{|c|}{ Human Resource Management Strategy } \\
\hline $\begin{array}{l}\text { Strategy } \\
\text { Focus }\end{array}$ & $\begin{array}{l}\text { Sustainability of human resources } \\
\text { optimally }\end{array}$ & $\begin{array}{l}\text { Regional Economic } \\
\text { Growth: }\end{array}$ & $\begin{array}{l}\text { Establishment of Work } \\
\text { Culture: }\end{array}$ \\
\hline Institutional & $\begin{array}{l}\text { 1. HR planning integrated } \\
\text { 2. Increased HR competencies } \\
\text { 3. Increased institutional } \\
\text { infrastructure }\end{array}$ & $\begin{array}{l}\text { 1.Increased labor } \\
\text { productivity } \\
\text { 2. The absorption of the } \\
\text { labor force in } \\
\text { accordance with the } \\
\text { level of human } \\
\text { resources }\end{array}$ & $\begin{array}{l}\text { 1.Increased labor } \\
\text { discipline } \\
\text { 2.Minimizing conflicts } \\
\text { 3.HR knowledge } \\
\text { development }\end{array}$ \\
\hline Economi & $\begin{array}{l}\text { 1.The growth of science and } \\
\text { technology mastery } \\
\text { 2.Increased achievement } \\
\text { motivation }\end{array}$ & $\begin{array}{l}\text { 1. realization of } \\
\text { Equitable } \\
\text { development } \\
\text { 2. human Resources } \\
\text { investment }\end{array}$ & $\begin{array}{l}\text { 1. The formation of } \\
\text { morale and morale } \\
\text { 2. Realization of Human } \\
\text { Relations }\end{array}$ \\
\hline Sosial Culture & $\begin{array}{l}\text { 1. Encouraging awareness in } \\
\text { human development }\end{array}$ & $\begin{array}{l}\text { 1. Increased KFM } \\
\text { 2. Increased human } \\
\text { resource development } \\
\text { 3. Increasing purchasing } \\
\text { power }\end{array}$ & $\begin{array}{l}\text { 1. Increased } \\
\text { achievement } \\
\text { motivation }\end{array}$ \\
\hline
\end{tabular}

\section{REFERENCES}

Atmosoeprapto, Kidarto.2001. Produktivitas Aktualisasi Budaya Perusahaan. Jakarta. Penerbit PT.Elex Media Kompotindo.

Aroef Matthias Prof.Dr.H dan Ir.Jusman Syafii Djamal.2009.Grand Tehno-Economic Strategi.Jakarta. Penerbit Mizan.

Baron Angela dan Michael Armstrong.2013. Human Capital Management. Terjamahan Lilian Juwono. Jakarta. PPM.

Becker Brian E, Mark A. Huslid. Richard W. Beatty. 2009. Transforming Talent. Terjemahan Abdul rosyid dan Wenda. Jakarta. Penerbit PPM.

BPS. 2008.Provinsi Bengkulu Dalam Angka. Bengkulu. Penerbit Badan Pusat statistik. 2010. Provinsi Bengkulu Dalam Angka. Bengkulu. Penerbit Badan Pusat statistik. 2012. Provinsi Bengkulu Dalam Angka. Bengkulu. Penerbit Badan Pusat statistik. 2013. Provinsi Bengkulu Dalam Angka. Bengkulu. Penerbit Badan Pusat statistik.

Djojohadikusom, Sumtiro. 1994. Dasar Teori Daerah Pertumbuhaan dan Daerah Pengembangan. Jakarta. Penerbit LP3ES.

Ginting,Basita. 2006. Pengembangan Masyarakat. Makalah disampaikan dalam kuliah di Institut Pertanian Bogor.

Meir, Gerald M. 1989. Leading Issues in economic Development. Oxford University Press.

Sinungan Muchdarsyah.2005. Produktivitas Apa dan Bagaimana. Jakarta. Penerbit. PT. Bumi Aksara.

Sumarsono, Sonny. 2003. Daerah Manajemen Sumberdaya manusia dan Ketenaga Kerjaan. Jakarta . Penerbit Graha Ilmu.

2009. Teori dan Kebijakan Publik Ekonomi Sumber Daya Manusia.Jakarta. Penerbit Graha Ilmu.

Sutrisno Edy. Dr. M.Si.2009. Manajemen Sumber daya Manusia. Jakarta.Penerbit. Prenada Media Group. 
Suryadi,. Ace. 1993. Hubungan Antara Sumberdaya manusia, daerah, Dan Ketanaga Kerjaan: Sebuah Mitos tentang Pengangguran Tenaga Kerja Terdidik. Jakarta. Penerbit Lembaga Demografi Fakultas Daerah Universitas Indonesia.

Undang-Undang Otonomi Daerah. 2006.Undang-Undang Republik Indonesia Nomor 32 Tahun 2004 tentang Pemerintahan Daerah. Jakarta. Penerbit Fokus Media.

Wirakarta Kusumah M.Djuahri., Mundiharno., Avanti Fontana. 1993. Sumberdaya manusia, Pasar Kerja, Dan Pertumbuhaan Daerah. Penerbit Lembaga Demografi Universitas Indonesia

Tirtosudramo,Riwanto.2008. Pengembangan Sumberdaya Manusia di antara Peluang dan Tantangan. Hal 13-39, Dari Human Capital Kehuman Devlopment.Jakrta. Penerbit LIPI Press.

Palan. R .2007. Competency Management. Terjemahan Octa Melia Jalal. Jakarta. Penerbit PPM.

Yuniarsih Tjutju.Prof.Dr. dan Dr. Suwatno. M.Si. 2008. Manajemen Sumber daya ManusiaTeori, Aplikasi dan Isu Penelitian. Bandung.Penerbit Alpabeta.

\section{AUTHOR's BIOGRAPHY}

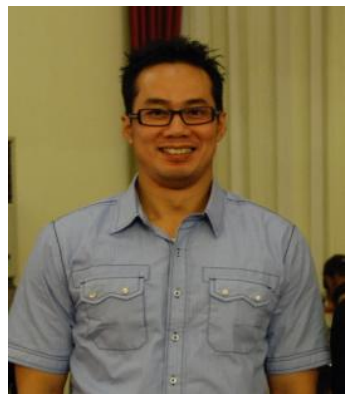

Achmad H Sutawidjaya is a lecture of Mercu Buana University, Jakarta, Indonesia. He obtained while the degree of Doctor of Business Administration (DBA) from San Beda College, Business School, Manila, Philippines in 2008. He finished Master of Commerce (M.Com) at the University of Wollongong, Australia in 1997. Then, He also Completed Master of Phillosopy (M.Phil) in Maastricht School of Management (MSM), Netherlands in 2000.

He had many experiences as a professional for 13 years in Banking and Corporate, such as BTPN, Bank Hastin, PT.SNN, and PT. NUArt.

Nowday, He is CEO / President Director of PT. Alfin Permata Jaya Engaged hearts Field outsourcing services, telecommunications and construction. He is also arrange as CEO Wedding Organizer (New Diamond) in Jakarta. 